\title{
IMPACT OF SECESSION MOVEMENTS ON THE TERRITORIAL POLITICAL SYSTEM OF THE WESTERN EUROPEAN REGION
}

\author{
Liudmyla KOVALEVYCH \\ Taras Shevchenko National University of Kyiv, Ukraine \\ ludmylkakovalevych@gmail.com
}

\begin{abstract}
Secessionism as a political and geographical phenomenon is characterized by a specific distribution area that allows researching its impact on different levels of the territorial political systems. This study examines the main influences of European secessionism on the political sphere of the region, which includes diversity of the political spectrum of modern Europe through the formation of non-governmental organizations at the European level and a number of secession regionalist parties at the national and regional level. Moreover, secession movements which are involved in the functioning of supranational EU institutions enhance their impact on regional and general policy of the EU. Most European ethno-regionalist parties are concentrated in three main areas (marine and oceanic coastline, the eastern periphery of the region and the area of the urban belt of Europe). The main component of secession movement's activity is the political one; as a result, they are primarily trying to achieve their goals through peaceful, democratic means. However, these movements become the factor of destabilization and disintegration of the political map of Europe which threaten European security, can lead to the formation of new states and change centers of power in the region.
\end{abstract}

Key words: secessionism, secession movements, regionalist party, territorial political system, European Union, political map.

DOI: https://doi.org/10.17721/2413-7154/2017.77.78-84

UDC: 911.3

\section{ВПЛИВ СЕЦЕСІЙНИХ РУХІВ НА ТЕРИТОРІАЛЬНО-ПОЛІТИЧНУ СИСТЕМУ ЗАХІДНОЄВРОПЕЙСЬКОГО РЕГІОНУ}

\author{
Людмила КОВАЛЕВИЧ \\ Київський начіональний університет імені Тараса Шевченка, Україна \\ ludmylkakovalevych@gmail.com
}

\begin{abstract}
Анотація: Сецесіонізм як політико-географічне явище характеризується конкретною територією поширення, що дозволяє досліджувати його вплив на територіально-політичні системи різного рівня. У цьому дослідженні розглянуто основні впливиєвропейського сецесіонізмунаполітосферу регіону, до якихвіднесено урізноманітнення політичного спектра сучасної Європи завдяки формуванню неурядових організацій на загальноєвропейському рівні та ряду сецесійних регіоналістських партій на національному та регіональному. Більш того, участь сецесійних рухів у функціонуванні наднаціональних інституцій Європейського Союзу посилює їхній вплив на регіональну та загальну політику $Є$. Більшість $€$ вропейських партій етнорегіоналістського спрямування сконцентровано в трьох основних зонах (морське та океанічне узбережжя, східна периферія регіону та територія міського поясу Європи). В діяльності сецесійних рухів домінує політична складова і вони, в основному, намагаються досягти своїх цілей мирними, демократичними засобами. Водночас, ці рухи є чинником дестабілізації та дезінтеграції на політичній карті Європи, які ставлять під загрозу систему європейської безпеки, можуть призвести до утворення нових держав та зміни центрів впливу в регіоні.
\end{abstract}

Ключові слова: сецесіонізм, сецесійні рухи, регіоналістські партії, територіально-політична система, Європейський Союз, політична карта.

DOI: https://doi.org/10.17721/2413-7154/2017.77.78-84

УдК: 911.3

Постановка проблеми. Сецесіонізм завжди $\epsilon$ не тільки суспільно-політичним, а й політикогеографічним явищем, бо фактично проектується на територію i може бути визначений на карті у вигляді зон (територій) поширення сецесіонізму. Розглядаючи територіально-політичний вимір сецесіонізму, науковцями було здійснено спроби типізації його за географічною складовою, зокрема його проекцією на політичний простір. Серед інших виділяється західноєвропейський різновид сецесіонізму, що характеризується переважанням дії

(C) Л. Ковалевич етно-конфесійного (3 гіпертрофованою роллю мовного чинника) та соціально-економічного факторів. Багата історія регіону дозволяє широко використовувати історичний фактор (в основному, у формі древньої державності). I, оскільки проблема сецесіонізму не є винятково внутрішньодержавною, а чинить значний вплив як на сусідні держави, так i на політичну сферу регіону в цілому, дослідження та аналіз подібного впливу сецесійних процесів дозволяє оцінити існуючі та передбачити можливі зміни територіально-політичних систем на національному та наддержавному рівні. 
Аналіз останніх публікацій i джерельної бази дослідження. Дослідженнями проблеми сецесіонізму займалися різноманітні вчені, як географи, так політологи. Зокрема, вагомий внесок в розвиток досліджень територіально-політичних систем здійснили Б. Яценко [8], М. Дністрянський, С. Трохимчук [7], сецесійних процесів А. Баранов [1], Н. Беліцер [2], Н. Фонсека [3], В. Лажнік [4], регіоналістських партійних систем Р. Дендой [9], Л. Девінтер [10], Д. Айхерт [11] та ціла плеяда інших вчених.

Основною метою даної роботи $є$ дослідження та аналіз впливу сецесійних рухів на територіальнополітичну систему західноєвропейського регіону, зокрема участь у міжнародних організаціях та наднаціональних інституціях Свропейського Союзу, особливості впливу на безпекову та геополітичну ситуацію регіону.

Виклад основного матеріалу. Цикл розвитку сецесійних рухів підпорядкований логіці етнополітичної мобілізації. Вони починають в ролі культурно-історичних товариств, тоді стають групами інтересів, а потім розділяються на терористичне крило і легальні партії («групи проникнення», entryist groups). Цей поділ, як зазначає A.I. Тевдой-Бурмулі, не перешкоджає загальному антицентралізму. Рівень неоднорідності сецесійного «потоку» залежить від того, наскільки його субкультура включена в регіональну культуру [9]. Наприклад, «ШиннФейн» в Північній Ірландії та «Еррі Батасуна» в Країні Басків досить популярні, як і Ліга Півночі в Італії. Навпаки, рухи бретонців і савойців проти Франції, Баварська армія звільнення у ФРН - маргінальні, хоча й голосні угруповання.

Відмінною рисою західноєвропейського сецесіонізму $\epsilon$ домінування політичних партій серед акторів, що його формують, і переважання «стандартизованої» політичної діяльності над іншими її формами. Відсутність серйозних перешкод для участі в регіональних та загальнодержавних виборах дозволяе навіть найбільш маргінальним рухам отримувати зовнішню респектабельність, як це відбувається у випадках окситанського, кастильського, ольстерського сецесіонізму тощо. Лише поодинокі рухи обмежуються громадсько-пропагандистською діяльністю. У той же час терористична діяльність, хоч i не $\mathrm{e}$ типовим інструментом політичної боротьби, досі притаманна деяким ідеологічно розвиненим рухам. У трьох випадках сецесіонізм виходить за рамки цивілізованого протистояння, оскільки представлений i терористичними групами: в Північній Ірландії (Ірландська республіканська армія), Країні Басків (Еускаді та Аскатасуна) i на Корсиці (Фронт національного звільнення Корсики); номінально вони діють і в Шотландії (Шотландська національновизвольна армія), Бретані (Бретонська революційна армія) і на Сардинії (Рух за автономну Сардинію) [5].

Оскільки, політичні партії є одним із політикогеографічних чинників i вагомим структурним елементом територіально-політичної системи суспільства, важливим проявом впливу сецесіонізму на політосферу регіону є формування регіоналістських партій сецесійного спрямування [2]. Загалом, регіоналістські партії існують в більшості держав Європи, за винятком малих (таких, як Мальта чи Люксембург). Оскільки, більшість сецесійних рухів локалізовано на території чотирьох держав - Великої Британії, Італії, Іспанії та Франції ці країни також характеризуються найбільшою кількістю регіоналістських партій. Виникнення та функціонування подібних партій та відповідних регіональних партійних систем $\epsilon$ свідченням розвинутої регіональної політичної культури та чітко сформованої регіональної ідентичності. Це стосується так званого інструментального елемента регіональної ідентичності, коли жителі не просто усвідомлюють існування свого регіону та володіють знаннями про його географічні межі (когнітивний елемент) або оперують певним набором емоцій відносно нього (аффірмативний елемент), а коли регіон використовується як база для соціальної та політичної мобілізації населення і колективної діяльності. Отже, наявність регіоналістських партій можна вважати інституційною ознакою розвиненої регіональної ідентичності та високої політичної культури. В інакшому разі, подібні партії відсутні або ж їхня діяльність носить маргінальний характер.

Важливу роль у формуванні та функціонуванні регіоналістських партій відіграє територіальна основа, адже вони, насамперед, покликані захищати інтереси конкретного, у більшості випадків периферійного, регіону. Їхньою ключовою ознакою $€$ прагнення реорганізації існуючої політичної сфери в країні та перерозподіл владних повноважень на користь регіонів за рахунок надання їм права на самоуправління. Однак, на думку Р. Дендоя, сучасне зростання популярності регіоналістських партій не $\epsilon$ простим відновленням конфлікту «центр-периферія», а часто несе в собі вимоги трансформації політичної та економічної структури держави, а інколи i перегляду їі територіальних меж [9].

Серед регіоналістських партій можна виділити окрему групу етнорегіоналістських, діяльність та ідеологія яких спрямовані на захист їхньої регіональної ідентичності, яка може конкурувати або конфліктувати із загальнонаціональною. Вони відстоюють інтереси регіонально зосереджених етнічних, етнокультурних чи лінгвістичних спільнот 3 широким спектром вимог, які направлені на трансформацію відносин між регіоном і державою, створення нової незалежної держави або ж приєднання до іншої [10].

Етнорегіоналістські партії є досить поширеними в Свропі (іх налічується близько сотні) як результат переважаючої дії етно-мовного чинника виникнення сецесіонізму. Оцінюючи особливості їхнього географічного розташування, ще дослідник Д. Сейлер відмітив, що більшість європейських партій етнорегіоналістського спрямування сконцентровано в трьох основних зонах. Першою є морська та океанічна периферія Європи (Північна Ірландія, Корсика, Країна Басків, Бретань та ін.). Саме периферійність цих територій, очевидно, дозволила зберегти їхні 
лінгвістичні і культурні особливості. Друга зона охоплює східну периферію Свропи, на території контакту католицької та православної релігій, Західної та Східної Свропи (територія колишньої Югославії, Румунія, Україна). Нарешті, третьою зоною $\epsilon$ регіони розміщені вздовж так званого «блакитного банана» (від південної Англії до півночі Італії). Ці території відповідають середньовічним автономним містам-державам (міський пояс Європи), які і визначали специфіку розвитку цього регіону (Фландрія, Північна Італія тощо) [9].

Серед великої кількості різноманітних типологій регіоналістських (етнорегіоналістських) партій найбільш вдалу запропонував Р. Дендой. Його типологія грунтується на цілях регіоналістських партій, котрі пов'язані 3 бажаним рівнем самоуправління для своїх регіонів, i на ступені радикальності вимог. Таким чином, залежно від кінцевої мети діяльності партії, він виділяє три головні типи: протекціоністські, децентралістські і сецесійні регіоналістські партії, які поділяються на менші підтипи (табл. 1). Причому, в одному i тому ж регіону можуть діяти партії як, наприклад, децентралістського, так і сецесійного спрямування (Країна Басків, Каталонія, Бельгія та ін.).

В рамках даного дослідження нас цікавлять саме сецесійні партії, тож розглянемо їх детальніше.

Сецесійні партії ставлять собі за мету домогтися виходу регіону зі складу тієї держави, до якої він належить. Такого роду вимоги роблять ці партії найбільш радикальними серед регіоналістських партій. В їхній діяльності важливим аспектом є чітка територіальна ідентифікація регіону, який претендує на незалежність, а також проблема визнання цієї незалежності міжнародною спільнотою. Іншими словами, якщо діяльність протекціоністських та децентралістських партій несе в собі загрозу внутрішньодержавному порядку, то діяльність сецесіоністських партій може підривати міжнародний порядок, нести загрозу міждержавним відносинам та регіональній безпеці.

В структурі сецесіоністських партій виділяються індепендистські, іредентистські та реюніоністські (ратахістські) партії. Основною ціллю індепендистських партій є здобуття повної незалежності для свого регіону на основі права народу на самовизначення. До них належать партії, що діють на території Корсики, Країни Басків, Галіції, Уельсу, Шотландії. Сюди можна віднести і партії, серед вимог яких не тільки незалежність власного регіону, а й приєднання до нього сусідніх 3 ним регіонів тієї ж держави (каталонська ERC виступає за створення незалежної Великої Каталонії і включення в неї також Валенсії та Балеарських островів).

Дещо складніша ситуація 3 розумінням іредентистських та реюніоністських партій. Якщо іредентизм є відображенням позицій еліти держави стосовно втраченої території, то позиція еліти i мешканців власне цих територій матиме характер вже реюніонізму - бажання повернутися до складу своєї історичної батьківщини. Відповідно іредентистські регіоналістські партії - це партії, котрі не тільки прагнуть незалежності від тієї держави до якої належить їхній регіон, але також виступають за приєднання до новоутвореної держави тих етнічних земель (іреденту), які в силу історичних обставин опинилися у складі інших держав. Класичним прикладом існування регіоналістського іредентизму $є$ іспанська частина Країни Басків [9]. Частина партій цього регіону виступають за об'єднання всіх баскських земель, що входять до складу як Іспанії, так і Франції, в єдину державу басків (Euskal Herria).

I, нарешті, останнім підтипом сецесійних партій $€$ реюніоністські партії. Реюніонізм значною мірою $\epsilon$ відповіддю етнічних меншин певних держав на іредентистські настрої в своїх історичних батьківщинах по той бік кордону. Головною особливістю таких партій є не прагнення незалежності регіону, а тільки приєднання до іншої вже існуючої держави. Хоча варто зазначити, що в останні десятиліття реюніонізм окремих регіонів знаходить все менше підтримки іредентистів на етнічній батьківщині, що в значній мірі продиктовано загрозами розвитку міждержавних конфліктів між сусідніми державами. Так, реюніоністські настрої на Аланських островах згасли і перетворилися на автономістські після того як Швеція відмовилася піднімати питання про повернення островів зі складу Фінляндії. У франкомовному науковому дискурсі часто для позначення реюніонізму застосовується термін ратахізм (rattachism). Ратахізм - це рух у франкомовній Валлонії за ii приєднання до Франції. Подібні партії також існують в бельгійській німецькомовній спільноті, а також Фландрії (виступають за приєднання до Нідерландів).

Регіоналістські партії, як і партії інших партійних родин, здатні поступово змінювати і адаптувати свої ідеологічні преференції в залежності від різних факторів: електоральних, демографічних, економічних і т.д. Рухомість ідеології регіоналістських партій торкається також радикальності їх устремлінь. Так, наприклад, галісійська партія BNG на початку свого існування стояла чітко на позиціях незалежності Галісії, однак $з$ часом іiі вимоги сконцентрувалися навколо проблеми самоврядування та визнання національної ідентичності галісійського народу. Подібно валлійська партія Plaid Cymru, виступаючи спочатку за широке самоврядування, з 2003 року перейшла на позиції здобуття повної незалежності для Уельсу [10].

Регіоналістські партії протягом останніх десятиліть почали відігравати значно активнішу роль в рамках національних політичних систем багатьох європейських держав, зокрема йдеться про Іспанію, Бельгію, Великобританію та Італію. Також процес євроінтеграції значно активізував процеси регіоналізму, у рамках якого політичні партії $\epsilon$ важливими акторами. Значні їхні зусилля зосереджені в рамках європейських структур і спрямовані на перерозподіл влади на користь регіонів.

Регіоналісти віддавна представлені у Європейському Парламенті. Так, у 1979 році в ньому 4 регіоналістські партії отримали місця: Національна партія Шотландії (SNP) долучилася до Свропейських 
Регіоналістські партії на території Європейського Союзу

\begin{tabular}{|c|c|c|c|c|}
\hline $\begin{array}{l}\text { Рівень } \\
\text { радика- } \\
\text { льності } \\
\text { політи- } \\
\text { чних } \\
\text { вимог }\end{array}$ & Тип & Підтип & $\begin{array}{l}\text { Характери- } \\
\text { стика вимог }\end{array}$ & Приклади \\
\hline \multirow[b]{2}{*}{$\begin{array}{l}\text { Слабкі } \\
\text { вимоги }\end{array}$} & \multirow[b]{2}{*}{$\begin{array}{l}\text { Протек- } \\
\text { ціоністські }\end{array}$} & $\begin{array}{l}\text { Консерва- } \\
\text { тивні }\end{array}$ & $\begin{array}{l}\text { Визнання, } \\
\text { захист }\end{array}$ & $\begin{array}{l}\text { - Словенська партія Каринтії (тепер - } \\
\text { EnotnaLista (Список Єдності) }\end{array}$ \\
\hline & & Партиципарні & $\begin{array}{l}\text { Участь, } \\
\text { доступ }\end{array}$ & $\begin{array}{l}\text { - SSW (Südschleswigsche Wählerverband) } \\
\text { - PNV (Partido Nacionalista Vasco), } \\
\text { Enbata, EMA (Ezkerreko Mugimendu } \\
\text { Abertzalea), EB (Euskal Batasuna) (Франція) }\end{array}$ \\
\hline \multirow{3}{*}{$\begin{array}{l}\text { Середні } \\
\text { вимоги }\end{array}$} & \multirow{3}{*}{$\begin{array}{l}\text { Децентра- } \\
\text { лістські }\end{array}$} & $\begin{array}{l}\text { Автоно- } \\
\text { містські }\end{array}$ & $\begin{array}{c}\text { Влада, } \\
\text { розподіл } \\
\text { Повноважень }\end{array}$ & $\begin{array}{l}\text { - Union Valdotaine (Вальд’Аоста), } \\
\text { - Union Democratique Bretonne (Бретань) } \\
\text { - Union du Peuple Alsacien (Ельзас) } \\
\text { - Convergencia i Unio (Каталонія) } \\
\text { - Coalicion Galega та Esquerda Galega (Галіція) } \\
\text { - Partido Nacionalista Vasco (Країна Басків в } \\
\text { Іспаніiі) }\end{array}$ \\
\hline & & $\begin{array}{l}\text { Федера- } \\
\text { лістські }\end{array}$ & $\begin{array}{c}\text { Влада, } \\
\text { розподіл } \\
\text { повноважень } \\
\text { за федера- } \\
\text { тивним } \\
\text { принципом } \\
\end{array}$ & $\begin{array}{l}\text { - Fryske Nasjonale Partij (Нідерланди) } \\
\text { - VU (Volksunie) (Фландрія) } \\
\text { - RW (Rassemblement Wallon) (Валлонія) } \\
\text { - FDF (Federalistes Democrates Francophones) } \\
\text { (Бельгія) }\end{array}$ \\
\hline & & $\begin{array}{l}\text { Конфеде- } \\
\text { ралістські }\end{array}$ & $\begin{array}{c}\text { Влада, } \\
\text { розподіл } \\
\text { повноважень } \\
\text { за федера- } \\
\text { тивним } \\
\text { принципом }\end{array}$ & - «Новий Фламандський Альянс» (Бельгія) \\
\hline \multirow{3}{*}{$\begin{array}{c}\text { Ради- } \\
\text { кальні } \\
\text { вимоги }\end{array}$} & \multirow{3}{*}{ Сецесійні } & $\begin{array}{l}\text { Індепен- } \\
\text { дистські }\end{array}$ & Незалежність & $\begin{array}{l}\text { - Movimentupa l'Autodertermina-zione, Corsica } \\
\text { Viva, Unita Naziunalista, Corsica Nazione, } \\
\text { Accolta Naziunale Corsa, Rinnovu Naziunale } \\
\text { (Корсика) } \\
\text { - Abertzaleen Batasuna (Країна Басків) } \\
\text { - Asamblea Nacional-Popular Galega (Галіція) } \\
\text { - Ligue Savoisienne (Савойя) } \\
\text { - Plaid Cymru (Уельc) } \\
\text { - Scottish National Party (Шотландія) } \\
\text { - ERC (Esquerra Republicana de Catalunya) } \\
\text { (Іспанія) }\end{array}$ \\
\hline & & $\begin{array}{l}\text { Іреден- } \\
\text { тистські }\end{array}$ & $\begin{array}{c}\text { Незалежність і } \\
\text { приєднання } \\
\text { сусідніх } \\
\text { етнічних } \\
\text { територій } \\
\end{array}$ & $\begin{array}{l}\text { - Herri Batasuna/Euskal Herritarok та Eusko } \\
\text { Alkartasuna (Країна Басків) }\end{array}$ \\
\hline & & $\begin{array}{c}\text { Реюніо- } \\
\text { ністські } \\
\text { (ратахістські) }\end{array}$ & $\begin{array}{c}\text { Приєднання } \\
\text { до сусідньої } \\
\text { держави }\end{array}$ & $\begin{array}{l}\text { - Valdotanian Union (Італія) } \\
\text { - Sudtiroler Volkspartei, Неimatbund та } \\
\text { Sudtiroler Freiheitlichen (Південний Тіроль) } \\
\text { - SinnFein (Північна Ірландія) } \\
\text { - RWF (Rassemblement Wallonie France) } \\
\text { (Валлонія) } \\
\text { - Сhristliche Volkspartei та Heimattreue Front } \\
\text { (Бельгія) } \\
\text { - Vlaams National Verbond (Фландрія) }\end{array}$ \\
\hline
\end{tabular}

Складено за матеріалами $[9,10]$ 
Прогресивних Демократів, Фламандський народний союз(VU) i Брюсельський Демократичний фронт франкофонів (FDF) вступили до Технічної групи безпартійних, а Південнотірольська народна партія (SVP) - до Європейської народної партії [11]. 3 часом представництво регіоналістських партій в Європарламенті постійно зростало, причому їхня приналежність до тієї чи іншої загальноєвропейської партії могла варіювати.

Також представники націоналістичних рухів активно співпрацюють на загальноєвропейському рівні. Так, у 1979 р. помірними націоналістамиавтономістами, що представляють інтереси національних меншин i добиваються розширення їхніх політичних прав, був утворений «Свропейський вільний альянс» (англ. European Free Alliance, $E F A$ ), який об'єднує, за власним визначенням, регіоналістські і цивільні національно-демократичні партії Свропи, які виступають за повну політичну незалежність і суверенітет або деволюцію влади та набуття автономії відповідними регіонами. На сьогодні Членами EFA є 38 партій з 17 країн Свропи, що мають досить широке представництво в органах влади: 12 депутатів Європарламенту (представники Шотландської національної партії, Партії Уельсу, Російський Союз Латвії, партії Каталонії та Валенсії), чисельні депутати національних парламентів та регіональних органів влади [3]. 32004 року Альянс став європейською політичною партією. Водночас, варто відмітити, що деякі великі регіоналістські партії, такі як Ліга Півночі (Італія) чи Баскська націоналістична партія (Іспанія/Франція), на даний час вже не входять до Альянсу.

У 1985 р. 47 регіонів Європи об'єдналися в «Асамблею Свропейських регіонів» (англ. Assembly of European Regions, AER), що проголосила такі програмні цілі:

- просування принципу взаємодопомоги та регіональної демократії;

- посилення політичного впливу регіонів у європейських інститутах;

- підтримка регіонів у розширенні Європи і в глобалізації;

- допомога у міжрегіональному співробітництві по всій Свропі та за іiі межами.

В даний час АЄР об'єднує 300 регіонів 334 країн, включаючи країни СНД, і 16 міжрегіональних організацій. Повноправними членами Асамблеї 3 України є Дніпропетровськ та Київ. Вона підтримує тісні зв'язки та постійно співпрацює 3 Радою Європи, різноманітними міжрегіональними асоціаціями, інституціями ЄС[2].

Варто відмітити, що несподіваний політичний успіх європейський сецесіонізм отримав завдяки утворенню ефективних союзів правих консерваторів i (зазвичай радикальніших) лівих, прикладом чого $€$ перебіг та результати електоральних процесів у Каталонії та Країні Басків. Зростання громадської підтримки та зміна політичної ситуації на користь здобуття незалежності або, принаймні, вищого рівня автономії завдячує виходу на національну та міжнародну політичну арену більш поміркованих i респектабельних партій, які очолюють харизматичні лідери. На відміну від своїх радикальних попередників (які інколи вдавалися і до терористичних актів), нові лідери (каталонець Артур Мас, шотландець Алекс Сальмонд та ін.) підкреслюють намагання добитися своєї мети тільки у мирний, демократичний спосіб. Особливо вражаючим є приклад Великобританії, де політичні сили сецесійного спрямування i тi, що виступають за збереження цілісності держави, протягом 2012-2014 рр. продемонстрували здатність вести ефективний діалог з опонентами і пошук консенсусу шляхом компромісів і взаємних поступок [2]. I хоча референдум був програний борцями за незалежність Шотландії (55\% опитаних проголосували проти), це стало зразком високої політичної культури та можливості вирішувати подібні суперечності шляхом переговорів.

Натомість у Каталонії через активну протидію центрального уряду проведення будь-якого референдуму було визнано неконституційним, i було здійснено лише опитування, яке відвідало 42\% населення, під час якого $88 \%$ учасників проголосували за створення незалежної Каталонії [11]. Наприкінці 2015 року парламент Каталонії прийняв резолюцію про початок процесу набуття незалежності від Іспанії і було заявлено, що у другій половині вересня 2017 року буде проведено референдум, незалежно від згоди на це офіційного Мадрида.

Варто відмітити, що не лише сецесійні рухи здійснюють вплив на політосферу європейського регіону, але й водночас функціонування ЄС вносить певні зміни у діяльність таких рухів. Здавалося б, в умовах сучасної об'єднаної Свропи зі зниженням функціональної ролі національних урядів сепаратизм втрачає всякий сенс. Проте, незважаючи на нерішучість ЄС щодо підтримки сецесійних рухів, європейська інтеграція надала нову можливість етнорегіоналізму для зміцнення своїх позицій. Стало зрозуміло, що інтеграція створила нову реальність, в якій вартість сецесії знизилася, а потенційні переваги (насамперед, економічні, зокрема відсутність митних та торгівельних бар'єрів) суверенітету в інтегрованій Європі значно зросли. Відповідно змінилися і настрої сецесійних партій, які стали прихильнішими до ідеї об'єднаної Європи, ніж були раніше [11]. Також сецесія в межах об’єднаної Європи надає можливість об'єднання регіонів, що знаходяться в межах різних держав (Країна Басків, Каталонія тощо). Тому, більшість сецесійних рухів взяли на озброєння доктрину розділу деяких держав Союзу, залишаючи при цьому непорушними зовнішні кордони ЄС (Шотландська національна партія, Ліга Півночі, Фламандський блок)[3].

Безпосередньою перевагою євроінтеграції також $є$ можливість участі сецесійних партій на європейському рівні, що забезпечує їхню легітимність, адже багато 3 них починали як маргінальні групи 3 невеликою кількістю регіональної влади і ще меншою потужністю на державному рівні. Таким чином, вигравши місце в Свропейському парламенті або отримавши повноваження в певній 
загальноєвропейській інституції, сецесійні групи здобувають політичну видимість. Також євроінтеграція відкриває ширші можливості обходу нібито «репресивних» національних систем. Замість того, щоб впливати на політичну систему на державному рівні, регіоналістські партії можуть натомість звернути свою увагу на європейські владні структури. Таке явище вже навіть отримало назву «системного зсуву» влади [10]. I якщо Європа продовжить інтегруватися, і все більше суверенної влади та можливостей самостійного прийняття рішень переходитиме від суверенних держав на загальноєвропейський рівень, то це створить ще більші політичні стимули для регіоналістських груп європеїзувати свою діяльність і таким чином впливати на загальноєвропейську політику, зокрема $\mathrm{i}$ в питаннях підтримки регіональних рухів.

Окрім взаємодії сецесійних рухів на наддержавному рівні та інституціями $\mathrm{CC}$, вони також впливають на адміністративно-територіальний устрій держав, де поширені. Таким чином, поруч 3 процесами євроінтеграції у більшості країн Європи відбувається регіоналізація. Хоча форми регіонального самоуправління всюди відрізняються, прослідковується певна загальна тенденція: розширення вимог регіонів щойно починається процес передачі їм повноважень. В Іспанії, де двигуном регіоналізації виступають Каталонія та Країна Басків, сьогодні вже сформувалися структури так званого «асиметричного федералізму». Навіть у такій централізованій державі як Франція в 2003 році було прийнято поправку до Конституції, яка закріпила «децентралізовану організацію» Республіки, і новий закон про децентралізацію, що представив численні повноваження місцевим органам самоуправління [6]. В результаті діяльності сецесійних партій також відбулася федералізація Бельгії. Таким чином, на сьогоднішній день у половині держав Євросоюзу регіональна влада має законодавчі повноваження i працює як «партнер» $Є C$.

Проте у ряді випадків сепаратистські рухи не обмежуються парламентськими формами боротьби за розширення політичних прав національних меншин, а вдаються і до екстремізму. Ескалація протистояння із залученням терористичних методів боротьби призводить до використання державою сили чи навіть жорстоких репресій. Окрім того, що вони кидають виклик національному політичному устрою держави, кінцевою метою сецесійних партій i рухів $є$ зміна міжнародного порядку. Це може викликати цілий комплекс ситуацій, починаючи від повного розпаду держави (у випадку Фламандського сецесіонізму), утворення нової держави (Шотландія) чи навіть приєднання відокремленої території до вже існуючої сусідньої держави. Будь-який $з$ цих сценаріїв призводить до якісних та кількісних змін на політичній карті регіону, геополітичної ситуації, перегляду кордонів та виникнення додаткових точок нестабільності. Це ускладнює політичну та економічну ситуацію в європейських країнах i не сприяє подальшій інтеграції в ЄС. Активність сецесійних рухів ставить під загрозу систему європейської безпеки, яка базується на суверенітеті, незалежності і територіальній цілісності держав, непорушності кордонів та мирному вирішенні конфліктів.

Висновки. Отже, сецесійні рухи впливають на територіально-політичні системи як національного (посилення регіоналізації та передача все більше повноважень регіонам), так наддержавного рівня. Регіоналістські партії, як важливий структурний елемент територіально-політичної системи суспільства, урізноманітнюють політичний спектр сучасної Свропи. Деякі 3 них вже входять до транснаціональної Європейської народної партії, тобто формують правоконсервативну частину партійно-політичного спектра, що $\epsilon$ частиною системного блоку. Відбувається утворення тактичних тимчасових союзів і пошук спільних інтересів між раніше більш чітко розмежованими політичними силами, що ускладнює сучасну політичну карту Європи. Налагоджуються тісні зв'язки регіональних лідерів 3 провідними інституціями та керівними органами Європейського Союзу. Налагоджуються також міжрегіональні мережі політичних партій та рухів на основі не так класичних партійних ідеологій, як знаходження спільних інтересів. Завдяки подібній діяльності сецесійних рухів на наддержавному рівні посилюється їхній вплив на регіональну та загальну політику ЄС. Доволі часто партії сецесійного спрямування здійснюють свою діяльність в обхід національного рівня, заявляючи про себе на загальноєвропейському.

I хоча вогнища сецесіонізму в Західній Європі вже давно перебувають в стані стійкої рівноваги i, зазвичай, у них на меті не створення незалежної держави, а досягнення максимальної національнокультурної, економічної та політичної автономії в рамках існуючих нині державних кордонів, останніми роками деякі сецесійні рухи здійснили ряд активних кроків у напрямі отримання незалежності (зокрема, в Каталонії та Шотландіï). Окрім того, що вони кидають виклик національному політичному устрою держави, кінцевою метою сецесійних партій і рухів $є$ зміна міжнародного порядку, що створює загрозу переділу політичної карти регіону, розхитування геополітичної ситуації, перегляду кордонів та виникнення додаткових точок нестабільності.

\section{References:}

1. Baranov A. Separatizm v sovremennom mire: Politiko-territorial'nyj aspect [Separatism in the Modern World: Political and Territorial Aspect]. Čelovek. Soobsestvo. Upravlenie.[Human. Community. Governance], Moscow, 2005, N 3, pp. 107-124 (In Russian).

2. Belìcer N. Regìonal'na ìdentičnìst' ì regìonal'nij separatizm u sučasnìj Êvropì [Regional identity and regional separatism in Modern Europe]. İnstitut gromadâns'kogo suspil'stva, 2013. Access mode: http://www.csi.org.ua/ 
www/?p=2735 (In Ukrainian).

3. Fonseka N. Problemy separatizma v sovremennoj Evrope [The problems of separatism in modern Europe]. Vestnik VGU. Seriâ : Istoriâ. Politologiâ. Sociologiâ. [Bulletin of the VSU. Series: History. Political science. Sociology], Voronezh, 2013, Issue 1, pp. 170-174. (In Russian).

4. Lažnìk V. Neviznanì deržavnì utvorennâ âk ob'êkti sučasnoï političnoï karti svìtu [Unrecognized state entities as objects of modern political map of the world]. Nauk. visn. Volin. nac. un-tu ìm. Lesì Ukraïnki. Geografičnì nauki. [Scientific bulletin of Lesya Ukrainka Volyn National University. Geographical sciences], 2008, Issue 1, pp. 202-211. (In Ukrainian).

5. Popov F. Geografiâ secessionizma v sovremennom mire. [Geography of secessionism in the modern world]. Moscow, Novyj Hronograf, 2012, 672 p. (In Russian).

6. Slabous-Luŝenko A. Regìonalìzaciâ ta iii rol'u sučasnìj sistemì mìžnarodnih vìdnosin [Regionalization and its role in contemporary international relations]. Aktual'nì problemi mižnarodnih vidnosin. [Actual problems of international relations]. Kyiv, 2010, vol. 94 (2), pp. 116-122. (In Ukrainian).

7. Trohimčuk S., Fedun' O. Politična geografiâ svitu : navč. posib. [The political geography of the world]. Kyiv, Znannâ, 2007, 422 p. (In Ukrainian).

8. Âcenko B. Politična geografiâ ta geopolitika : navč. posib. [Political Geography and Geopolitics].Eds.: B. Âcenko, V. Stafijčuk, U. Brajčevs'kij. Taras Shevchenko National University of Kyiv. Kyiv, Libìd', 2007, 255 p. (In Ukrainian).

9. Dandoy R. Ethno-regionalist parties in Europe: a typology. Perspectives on Federalism, 2010, Vol. 2 (2), pp. 194-220.

10. De Winter L. A Comparative Analysis of electoral, office and policy success of ethnoregionalist parties. Regionalist Parties in Western Europe, L. De Winter, H. Tursan, London, Routledge, 1998, pp. 204-247.

11. Eichert D. Separation amidst Integration: The Redefining Influence of the European Union on Secessionist Party Policy. JIOS, 2016, Vol. 7, Issue 2, pp. 63-77. 